\title{
A gyermekvállalás árnyékára és a teljes termékenységi ráta Magyarországon
}

\author{
PÁSZTOR SZABOLCS \\ mesterszakos egyetemi hallgató, Budapesti Corvinus Egyetem, Közgazdaságtudományi Kar \\ E-mail: pasztor.szabolcs93@gmail.com
}

\begin{abstract}
Magyarországon a teljes termékenységi ráta a rendszerváltás óta meredeken csökken. Az arányszám ráadásul az 1980-as évek második fele óta messze elmarad a reprodukciós szinttől, a népességszám 1980 óta fogy. Releváns tehát a kérdés, hogy milyen tényezők húzódhatnak meg a ráta tartósan alacsony szintje és továbbra is csökkenő trendje mögött. Cikkemben Walker (1995) nyomán elkészítem a gyermekvállalás árnyékárának idősorát Magyarországra, amellyel empirikus adatok alapján becslést adok az első gyermek vállalása következtében felmerülő költségekre. Bemutatom az összefüggést a teljes termékenységi ráta alakulása és az átlagos anyai életkor kitolódása között. Az ütem és paritás szerint korrigált teljes termékenységi rátát először az árnyékárak idősorainak segítségével vizsgálom, majd parciális elemzésnek vetem alá. Az eredmények alapján ajánlásokat fogalmazok meg a gazdaságpolitikai döntéshozó számára a termékenység pozitív irányú ösztönzésére vonatkozóan.
\end{abstract}

Journal of Economic Literature (JEL) kódok: J11, J13

Kulcsszavak: árnyékár, gyermekvállalás, halasztó magatartás, teljes termékenységi ráta

\section{Bevezetés}

Egy ország demográfiai folyamatainak elemzéséhez a leggyakrabban használt méröszám a teljes termékenységi ráta (TTR). A mutató rövid definíciója: egy adott idöpontban a szülőképes korú (15-49 éves) női népességre jutó átlagos születésszám. Az arányszám megmutatja, hogy a szülőképes korú nők hány gyermeket fognak világra hozni szülöképes koruk alatt átlagosan és várhatóan (Husz 2006), implicit feltételezve, hogy (1) a női populáció megoszlása állandó, (2) a korévenkénti teljes termékenységi ráta időben változatlan, (3) minden nő megéli a termékeny kora végét és (4) nincs, vagy kiegyenlített a migráció (Sato 2007). A ráta reprodukciós szintje ${ }^{1}$ elméletileg 2, feltéve, hogy a teljes népesség pontosan fele nő és minden nő megéli a termékeny kora

1 A reprodukciós szint az az érték, amely mellett a népességszám állandó. 
végét. Az egyenlőtlen férfi-nő arány és a korai halálozások miatt azonban ennél magasabb érték szükséges a reprodukcióhoz, amely így a fejlett gazdaságokban 2,1 körül alakul². A TTR ezek alapján képes elörevetíteni a népességszám várható alakulását, amennyiben a feltevések teljesülnek.

Magyarországon a rendszerváltást követően az anyák átlagos életkora (az első gyermek születésekor) egyre későbbre tolódott. A trendet Kamarás (2001) a családalapítási szokások megváltozásával magyarázza. A halasztó magatartás torzítja a TTR-t, így értelmezéséből téves következtetésekre juthatunk. Az első gyermek vállalásának későbbre tolódása azt eredményezi, hogy az adott évben a fiatalabb korosztályok nem vállalnak gyermeket. Az idősebb korosztályokra ez nem vonatkozik, tehát az adott évben ők már túl vannak az első gyermek vállalásán. Ezek következtében a TTR értéke jelentös mértékben lecsökken, hiszen nem számol azzal, hogy a fiatalabb korosztályok később „bepótolhatják” az elmaradt gyermekvállalást. Ha a TTR visszaesésekor halasztó magatartást mutató korosztályok szülöképes koruk végéhez közeledve mégis gyermeket vállalnak, az a TTR növekedését vonja maga után. A TTR növekedése ekkor (a halasztó magatartáshoz hasonlóan, de ellentétesen) nem jelenti a népességszám várható növekedését, csupán a mutató számításának következménye (Berde-Németh 2015). A TTR a kohorsz befejezett termékenységi rátával összevetve ellenőrizhető. Berde és Németh (2015) kimerítő elemzést nyújt a hagyományos TTR és két korrigált mutató összehasonlításáról. Eredményeik alapján a Bongaarts-Feeney-féle ütem és paritás szerint kiigazított teljes termékenységi rátát ${ }^{3}$ ajánlják demográfiai elemzésekhez. A szerzőpáros a korrigált ráta idősorát többek közt Magyarországra is számszerűsítette és az adatokat rendelkezésemre bocsátotta.

A TTRp* tehát már nem tartalmazza a halasztó magatartás torzító hatását, azonban még így is jóval a reprodukciós szint alatt marad ${ }^{4}$. Ráadásul a mutató alakulása csökkenő trendet mutat, amely pesszimista képet fest. Cikkemben Walker (1995) munkája alapján elkészítem Magyarországra a gyermekvállás árnyékárának idősorát, amely az első gyermek vállalásának relatív költségét mutatja különböző korévekre. Az idősor segítségével így nemcsak a halasztó magatartás magyarázható, de a TTRp* csökkenő trendje mögött meghúzódó tényezők elemzése is lehetővé válik. Cikkem a következőképpen épül fel. A 2. fejezetben ismertetem Walker neoklasszikus modelljét, amely elsőrendű feltételének eredménye a gyermekvállalás árnyékára. A 3. fejezetben részletezem az árnyékár struktúráját, valamint a modell paraméterezését és a

2 Angliában például 2,0750 (Espenshade és szerzőtársai 2003).

3 Ütem és paritás szerint korrigált teljes termékenységi rátát Kohler és Ortega (2004), illetve Bongaarts és Feeney (2008) szerzőpáros definiált. A Bongaarts-Feeney-féle korrigált rátára cikkemben a TTRp* jelöléssel hivatkozom.

4 A halasztó magatartás a népesség elöregedését okozza. Ekkor a halálozási arány nő, ami a $\mathrm{TTRp}^{\star}$ reprodukciós szintjének növekedését vonja maga után. Ez azt jelenti, hogy a TTRp* növekedése ellenére a népesség tovább fogyhat. 
Magyarország-specifikus feltevéseket. A 4. fejezetben a halasztó magatartást magyarázó tényezőket, az 5. fejezetben pedig a TTRp* csökkenését okozó tényezők hatását elemzem. Végül összefoglalom a főbb eredményeket, valamint gazdaságpolitikai ajánlásokat teszek a termékenység pozitív irányú befolyásolására vonatkozóan.

\section{Walker neoklasszikus modellje}

Walker (1995) neoklasszikus modelljét az 1970-es és 1980-as évek svéd demográfiai folyamatai insipirálták. Svédország teljes termékenységi rátája a reprodukciós szint körül alakult, azonban az 1970-es évektől a gyermekvállalás későbbre tolódása volt jellemző. Magyarországon a rendszerváltást követően jelentkezett hasonló jelenség, azonban a halasztó magatartástól szürt TTRp* is csökkenő trendet mutat. Így Magyarország esetében két kérdés is releváns: (1) milyen tényezők állnak a halasztó magatartás mögött, (2) milyen tényezök okozzák a termékenység tartós csökkenését. Walker (1995) modellje mindkét kérdés elemzésére alkalmas, így a fejezet további részében bemutatom a modell rövid levezetését.

A modell egyetlen szereplöje egy reprezentatív nő. Legyen az időhorizont $t=1, \ldots, T$, hasznosság pedig a gyermekvállalásból $\left(C_{t}\right)$ és a kompozit jószág $\left(x_{t}\right)$ fogyasztásából származik. $C_{t}=v\left(n_{s, t}\right)$, tehát $C_{t}$ függ a gyermekek számától ( $n$ ) és

életkorától $(s)$ is. A gyermekek száma: $n_{t}=\sum_{l=1}^{t} b_{l}$, ahol $b_{t}$ a $t$. időszaki termékenység. Az életpálya-hasznosság ekkor a következőképpen adható meg:

$$
U=\sum_{s=t}^{T} \beta^{s}\left[v\left(n_{s}\right)+u\left(x_{s}\right)\right],
$$

ahol a fogyasztói preferenciák intertemporálisan és jószágcsoportonként szeparálhatóak, $\delta_{t}=\frac{1}{(1+r)^{t-1}}$ a szubjektív diszkontfaktor, $v($ ) és $u($ ) pedig jól viselkedő hasznossági függvények. A szereplő két tevékenysége: munka $\left(h_{t}\right)$, illetve a gyermek gondozása $\left(f\left(n_{t}\right)\right)$, az ezek rendelkezésre álló idő pedig normálva 1. A gyermekre fordított kiadások a $t$. időszakban: $g\left(n_{t}\right) \cdot \phi^{j}$ az adott év szülésre és gyermek-

gondozásra fordított része. Ekkor $f\left(n_{t}\right)=\sum_{j=0}^{s_{p}} \phi^{j} b_{t-j}$ az összes gyermekgondozásra fordított idő, ahol $S_{p}$ a gyermek maximális, szülői gondozást igénylő kora. Legyen a szülői és intézményi gyermekgondozás egymás tökéletes helyettesítői. A gyermekre fordított közvetlen kiadások a gyermek $s$. életévében a $t$. évben: $m_{t}^{s}$ a gyermek $M$. éves koráig jelentkeznek $\left(m_{t}^{s}=0, s \geq M\right)$. A családi pótlék $\alpha_{t}$, az intézményi 
gyermekgondozás díja pedig $c_{t}^{s} \cdot c_{t}$ akkor merül fel, amikor az anya dolgozik $\left(h_{t}\right)$ és ameddig a gyermek nem múlt el $S_{p}$ éves $\left(c_{t}^{s}=0, s>S_{p}\right)$. A gyermekvállalás miatt felmerülö közvetlen kiadások ekkor ( $n_{t}$ függvényében):

$$
g\left(n_{t}\right)=\sum_{j=0}^{M}\left(m_{t}^{j}-\alpha_{t}\right) b_{t-j}+h_{t} \sum_{j=0}^{S_{p}} c_{t}^{j} b_{t-j}
$$

Legyen a 0 . időszaki humán tőke $1\left(k_{0}=1\right)$. A humán tőke akkumulálódása a következőképpen jellemezhető: $k_{t}=\exp \left(\mu_{0}+\mu_{1} \sum_{j=1}^{t-1} h_{t}\right)$. A munkabér egyenlő a reálbérleti díj és a humán tőke szorzatával: $w_{t}=\omega_{t} k_{t}$. A tőkepiacok tökéletesek. A reálkamatláb $(r)$ konstans, a diszkontfaktor $\delta_{t}=\frac{1}{(1+r)^{t-1}}$. A gyermekgondozási segély legyen $\theta_{t}$. A transzferek forrása az ad valorem munkaadó, melynek kulcsa $\tau_{t}$. A házastárs jövedelmének jelenértéke $A_{0}$, a kompozit jószág ára $p_{t}$. A reprezentatív nő döntési problémája ekkor a következő:

$$
\begin{gathered}
\max _{\left\{b_{1}, x_{1}, b_{2}, x_{2}, \ldots, b_{T}, x_{T}\right\}} \sum_{t=1}^{T} \beta^{s}\left[v\left(n_{s}\right)+u\left(x_{s}\right)\right] \\
\sum_{t=1}^{T}\left(p_{t} x_{t}+g\left(n_{t}\right)\right) \delta_{t}=A_{0}+\sum_{t=1}^{T}\left(1-\tau_{t}\right) w_{t} h_{t} \delta t \\
w_{t}=\omega_{t} k_{t}=\omega_{t} \exp \left(\mu_{0}+\mu_{1} \sum_{j=1}^{t-1} h_{t}\right) \\
n_{t}=\sum_{j=1}^{t} b_{t-j} \\
0 \leq b_{t} \leq B .
\end{gathered}
$$

A feltételes szélsőérték-feladat a következő alakot ölti:

$$
\begin{gathered}
\mathrm{M}=\sum_{t=1}^{T} \beta^{s}\left[v\left(n_{s}\right)+u\left(x_{s}\right)\right] \\
-\lambda_{1}\left(\sum_{t=1}^{T}\left(p_{t} x_{t}+g\left(n_{t}\right)\right) \delta_{t}-A_{0}-\sum_{t=1}^{T}\left(1-\tau_{t}\right) w_{t} h_{t} \delta t\right)- \\
-\lambda_{2}\left(w_{t}-\omega_{t} \exp \left(\mu_{0}+\mu_{1} \sum_{j=1}^{t-1} h_{t}\right)\right)-\lambda_{3}\left(n_{t}-\sum_{j=1}^{t} b_{t-j}\right) \\
t=1, \ldots, T
\end{gathered}
$$




$$
\begin{gathered}
\frac{\partial \mathrm{M}}{\partial x_{t}}=\beta^{t-1} u^{\prime}\left(x_{t}\right)-\lambda_{1} p_{t} \delta_{t}=0 \\
\frac{\partial \mathrm{M}}{\partial b_{t}}=\sum_{j=t}^{T} \beta^{j-1} v^{\prime}\left(n_{j}\right)-\lambda_{1} \pi_{t}=0 \\
t=1, \ldots, T,
\end{gathered}
$$

ahol $\lambda_{1}$ az életpálya-költségvetési korláthoz tartozó Lagrange-szorzó és (1) alapján egyenlő az adózott munkabér határhasznával. $\pi_{t}$ a gyermekvállalás teljes költsége:

$$
\begin{aligned}
\pi_{t} & =\sum_{j=0}^{T-t}\left(\left(1-\tau_{t+j}\right) w_{t+j} \phi^{j}-\theta_{t+j}\right) \delta_{t+j}+ \\
& +\sum_{j=0}^{T-t}\left(m_{t+j}^{j}-\alpha_{t+j}+\left(1-\phi^{j}\right) c_{t+j}^{j}\right) \delta_{t+j}+ \\
& +\mu_{1} \sum_{j=1}^{T-t}\left(\sum_{l=0}^{j-1} \phi^{l}\right)\left(1-\tau_{t+j}\right) h_{t+j} w_{t+j} \delta_{t+j} .
\end{aligned}
$$

Az elsőrendü feltételek (1) második egyenlete alapján látható, hogy a korai gyermekvállalást ösztönzi az, ha a szubjektív diszkontfaktor kisebb mint 1. A korai gyermekvállalás ellenösztönzője lehet $\pi_{t}$ magas szintje, mivel a nők döntésüknél figyelembe veszik a gyermek „árát”.

$\pi_{t}$ a $t$. időszaki gyermekvállalás teljes költségének jelenértéke, másképpen a gyermekvállalás árnyékára. $\pi_{t}$ komponenseit és paraméterezését a 3 . fejezetben részlete-

zem. Legyen $V_{t}\left(n_{t}\right)=\sum_{j=t}^{T} \beta^{j-1} v^{\prime}\left(n_{j}\right)$. Ekkor:

$$
\frac{V_{t+1}}{V_{t}}=\frac{\pi_{t+1}}{\pi_{t}},
$$

amely alapján egyensúlyban a gyermekvállalás egy periódussal való késleltetésének határhaszna egyenlő az egy periódussal való késleltetés határköltségével.

Walker fontosnak tartja kétféle elemzési megközelítés elhatárolását. Az evolúciós megközelítés során az életpálya-jövedelem változatlan, a komparatív statikai elemzés során általában változik. Cikkem során a komparatív statikai elemzésre fókuszálok, mivel feltételezésem szerint a magyar folyamatok alakulása mögött olyan változások húzódnak meg, amelyek jelentősen befolyásolták az életpálya-jövedelem mértékét. Walker felhívja a figyelmet arra, hogy amennyiben a komparatív statikai elemzések során a jövedelmi és helyettesítési hatás ellentétes, akkor az eredmények félrevezetőek lehetnek. Ezért a szerző azzal a feltételezéssel élt, hogy a jövedelmi hatás a befejezett termékenységen nulla, így a jövedelmi hatás csak a gyermekvállalás időzítését befolyásolja, a gyermekek számát nem. Elemzésem során én is hasonló feltételezéssel élek, valamint Walkerhez hasonlóan kizárólag az első gyermek vállalásának időzítését vizsgálom, így eredményeim a jövedelmi hatás torzításától mentesek. 
A gyermekvállalás árnyékárának magyar adatokkal való paraméterezése előtt bemutatom Walker komparatív statikai elemzését a modell változóira, így láthatóvá válik, hogy a megfigyelt változások valóban a várt irányba mozgatják-e a termékenység alakulását. Az olyan változások, amelyek meredekebbé teszik az árnyékárat ${ }^{5}$, a korai gyermekvállalást ösztönzik. Az olyan változások, amelyektöl az árnyékár laposabb ${ }^{6}$, a késői gyermekvállalást ösztönzik. Nemcsak a változások mértéke, hanem az időzítése is fontos. Ceteris paribus növekvő bérek a korai gyermekvállalást ösztönzik ${ }^{7}$. Egy adott időszaki átmeneti munkabérváltozás hatása annál jelentősebb, minél korábban történik ${ }^{8}$. A gyermekre fordított kiadások növekedése drágítja a gyermekvállalást, a transzferek emelkedése csökkenti a gyermekvállalás árnyékárát ceteris paribus. $\mu_{1}$ növekedése esetén ceteris paribus az árnyékár meredekebb lesz, tehát ez a korai gyermekvállalást ösztönzi.

A 3. fejezetben részletesen tárgyalom a gyermekvállalás árnyékárának komponenseit. Ezután elvégzem az egyenlet paraméterezését magyar adatok segítségével a 2000-2014-es időhorizontra. Az így kapott idősorok segítségével a 4. fejezetben feltárom a magyarországi halasztó magatartás mögött meghúzódó tényezőket, majd az 5. fejezetben a TTRp ${ }^{*}$ csökkenését okozó változásokat.

\section{A gyermekvállalás árnyékára}

Az árnyékár közgazdasági interpretációja a következő. Egy feltételhez tartozó árnyékár megadja, hogy mennyivel változik az optimális célfüggvényérték, ha a feltételen egy egységnyit „lazítunk” (Temesi-Varró 2007). Walker modelljében a gyermekvállalás árnyékára a következőképpen értelmezhető. Az árnyékár megadja, hogy mennyivel nő a maximalizált fogyasztás optimumban vett értéke, ha az árnyékárhoz tartozó korláton egy egységnyit lazítunk, tehát az adott nő plusz egy gyermeket vállal. A fogyasztásnövekmény a gyermekvállalás határhaszna, az árnyékár pedig a gyermekvállalás határköltsége. Mivel optimumban $M U=M C$, így a gyermekvállalás határhaszna egyenlö a gyermekvállalás határköltségével, vagyis az árnyékárával. Az árnyékár ezek alapján megadja, hogy egy adott nő mennyit lenne hajlandó fizetni azért, hogy plusz egy gyermeket vállalhasson, vagy másképpen, mennyivel kellene kompenzálni azért, hogy ne vállaljon plusz egy gyermeket ${ }^{9}$.

5 Walker a meredekebb árnyékár alatt azt érti, hogy a szumma tagjai időben növekvőek.

6 A laposabb árnyékár azt jelenti, hogy a szumma tagjai időben csökkenőek.

7 Itt természetesen a nettó bér számít, az adókulcs változásának hatása ellentétes.

$8 \mathrm{Ez}$ a diszkontálás következménye.

9 A cikk során végig az első gyermek vállalását, tehát az anyává válást fogom elemezni. 
A 2. fejezetben ismertettem Walker modelljét. A levezetés eredményeként adódott a (2) egyenlet, amely a gyermekvállalás árnyékára, vagy másképpen a gyermekvállalás alternatívaköltsége. Az áttekinthetőség végett az egyenlet még egyszer:

$$
\begin{aligned}
\pi_{t} & =\sum_{j=0}^{T-t}\left(\left(1-\tau_{t+j}\right) w_{t+j} \phi^{j}-\theta_{t+j}\right) \delta_{t+j}+ \\
& +\sum_{j=0}^{T-t}\left(m_{t+j}^{j}-\alpha_{t+j}+\left(1-\phi^{j}\right) c_{t+j}^{j}\right) \delta_{t+j}+ \\
& +\mu_{1} \sum_{j=1}^{T-t}\left(\sum_{l=0}^{j-1} \phi^{l}\right)\left(1-\tau_{t+j}\right) h_{t+j} w_{t+j} \delta_{t+j} .
\end{aligned}
$$

Az egyenlet jól látható módon három komponensből áll ${ }^{10}$. A (2.1) komponens a gyermekvállalás miatt kiesett nettó munkabér és az ezt részben pótolni kívánó gyermekgondozási segély jelenértéke. A (2.2) komponens a gyermek miatt felmerülő közvetlen kiadásokat tartalmazza. A komponens első fele a közvetlen kiadások a családi pótlékkal csökkentve, a második fele pedig az intézményi gyermekgondozás díja, ami akkor merül fel, amikor a gyermek nem áll szülöi gyermekgondozás alatt. A (2.3) komponens a gyermekvállalás miatt nem realizálódott humántőke-akkumuláció. Walker felhívja a figyelmet arra, hogy $\pi_{t}$ endogén, így a modellre fennáll a Lucas-kritika (Lucas 1976). A döntési környezetet módosító változások nyilvánvalóan befolyásolják a háztartások döntését ${ }^{11}$, ezáltal az árnyékár szerkezete változhat. Az árnyékár helyes értelmezése ezek szerint az optimumban vett árnyékár. Elemzésem során Walker-hez hasonlóan változatlannak tekintem a formulát, ezáltal a konkrét értékek nem értelmezhetőek, azonban a relatív változások informatívak maradnak.

\subsection{A kiinduló paraméterezés}

A (2) egyenlet paraméterezése során feltételezem a tökéletes információt. Ennek értelmében minden gazdasági szereplő ismeri a munkabér mértékét korcsoportonként, az erre számítandó effektív adókulcsot, az intézményi gyermekgondozás diját, a humán tőke hozamát és így tovább. Emellett a szereplökről feltételezem a teljes racionalitást, tehát a várakozásaik is racionálisak. A racionális várakozások elmélete szerint a szereplők minden rendelkezésre álló információt felhasználnak a változók jövőbeli alakulásának előrejelzésekor, tehát tökéletes informáltság mellett a szereplők előrejelzése

10 Walker az árnyékár komponenseit $T-t$-ig szummázta. Ekkor azonban a nyugdíjkorhatárhoz közeli gyermekvállalás árnyékára torzul. Éppen ezért a számolás során minden komponensben a gyermek 18 éves koráig szummáztam. A diszkontfaktor miatt a jövőbeli értékek 0-hoz konvergálnak, így elegendő ezt az időszakot tekinteni.

11 A modell feltételezi, hogy $\phi^{j}$ exogén, pedig valójában $\phi^{j}=f(w, \tau, \theta, \alpha, \ldots)$. 
is tökéletes ${ }^{12}$. Egyensúly esetén a jövőbeli értékek csak egy $\varepsilon: N(0, \sigma)$ információs sokkban térhetnek el a jelenlegitől. Ekkor egy tetszőleges $\mathrm{X}$ változó alakulása a várakozások szerint ${ }^{13}$ :

$$
\begin{aligned}
& X_{t+1}=X_{t}+\varepsilon \\
& E\left(X_{t+1}\right)=X_{t} .
\end{aligned}
$$

Mivel csak a $t$. időszaki érték ismert, így $t$-ben a legjobb elörejelzés:

$$
\begin{gathered}
E\left(X_{t+j}\right)=X_{t+k-1}, \forall j \\
E\left(X_{t+j}\right)=X_{t}, \forall j
\end{gathered}
$$

A (3.4) egyenlet szerint ekkor minden változó a $t$. periódusban rendelkezésre álló információ szerint alakul. A továbbiakban ismertetem a magyar adatokkal való paraméterezés föbb feltevéseit és korlátait.

A (2) egyenlet paraméterezése empirikus adatok segítségével történik. A svéd statisztika régóta és rendkívül pontosan gyüjti a fontos adatokat, amelyeket többnyire elérhetővé is tesz. Ezzel szemben Magyarországon a rendszerváltás előtt az adatokat változékony szemléletben írták össze, és sokszor felmerül az idősorok konzisztenciájának kérdése. A rendelkezésre álló idősorok korlátot szabnak az elemzésnek, így a vizsgálódás horizontja a 2000-2013-as időszakra rövidül ${ }^{14}$. Az adatok forrása szerteágazó, ezt részletesen az 1. táblázat tartalmazza. A legtöbb változó alakulása közvetlenül megfigyelhető, azonban néhány változó megfigyelése nehézkes, így a paraméterezés némi számítást igényel. A szükséges számításokat a függelékben részletezem. Minden pénzben mért érték 2014-es árszínvonalon értendő.

Walker modelljébenéves munkabér szerepel. Magyaradat csakazéves bruttóátlagkeresetről áll rendelkezésre, azonban a munkabér és a kereset korrelációja nagyon magas, így a kereset a munkabér megfelelő proxyja. Az elemzés időhorizontjára különböző forrásokból állítható össze az éves női bruttó átlagkereset korcsoportok szerint $\left(w_{t}\right)$. A korcsoportok hossza forrásonként eltérö, ezért például a 21-25 és a 26-30 éves korosztály átlagbére 2006-tól azonos. A várható kereset ismeretében kalkulálható az effektív adókulcs $\left(\tau_{t}\right)$. Effektív adókulcsként definiálom az adott keresetre számolt személyi jövedelemadó és a munkavállalói járulékok összegét. $w_{t}$ és $\tau_{t}$ ismeretében kalkulálható az éves nettó átlagkereset, amely a munkavállalásból származó rendelkezésre álló jövedelem proxyja.

12 Walker ezt a feltevést az angol perfect foresight assumption kifejezéssel illeti.

13 Ekvivalens feltételezés, hogy a változók elsőrendü Markov-folyamatot követnek.

14 A szűk keresztmetszet elsősorban a nők munkabérének korcsoportos megoszlása, mivel a 2000-es évek előtt kevésbé részletes adatgyüjtés volt jellemző. 


\section{1. táblázat: A (2) egyenlet változói, a változók tartalma és értéke, vagy forrása}

\begin{tabular}{cll}
\hline Változó $^{15}$ & Tartalma & Érték/Forrás \\
\hline$w_{t}$ & Bruttó átlagkereset korcsoportonként & Saját számítás (ld. A.1.) \\
$\tau_{t}$ & Effektív adókulcs korcsoportonként & Saját számítás (ld. A.2.) \\
$\phi^{j}$ & A szülői gyermekgondozás az összes & $\phi^{j}=1.0,0 \leq j \leq 2$ \\
& gyermekgondozás arányában & $\phi^{j}=0.5,3 \leq j \leq 6$ \\
$\theta_{t}$ & Gyermekgondozási segély (gyes) & $\phi^{j}=0.0,7 \leq j$ \\
$m_{t}^{s}$ & Közvetlen kiadások a gyermekre & KSH (2016a) \\
$\alpha_{t}$ & Családi pótlék & Saját számítás (ld. A.3.) \\
$c_{t}^{s}$ & Az intézményi gyermekgondozás díja & Saját számítás (ld. A.4.) \\
$\mu_{t}$ & A humán töke hozama & Saját számítás (ld. A.5.) \\
$r$ & Reálkamatláb & Campos és Joliffe (2007) \\
$\delta_{t}$ & Diszkontfaktor & Világbank (2016) \\
$h_{t}$ & A munkával töltöt idő az éven belül & $\delta_{t}=\frac{1}{(1+r)^{t-1}}$ \\
$T$ & Nyugdíjkorhatár & 1
\end{tabular}

$\phi^{j}$ a kiinduló paraméterezésnél exogén paraméter. A 3. fejezet elején ismertettem, hogy $\phi^{j}$ valójában endogén, de empirikusan megfigyelhető, hogy a nők általában mennyi idöt töltenek otthon a gyermekkel és mikor térnek vissza rész-, illetve teljes munkaidőben a munkapiacra.

A kiinduló paraméterezés során feltetételezem, hogy az anyák a gyermek 3 éves koráig nem dolgoznak, ezt követően részmunkaidős állást vállalnak, majd a gyermek 7 éves korától teljes munkaidőben dolgoznak egészen a nyugdijkorhatárig. $\phi^{j}$ így összefüggésben áll a tankötelezettséggel, hiszen a gyermekek tipikusan 3-6 éves korukig járnak óvodába, majd 7 éves koruktól kezdődik az alapfokú oktatás ${ }^{16}$. A változóra végzett érzékenységvizsgálat segítségével elemezhető a feltevés robusztussága.

15 A változók indexei a következőképpen értelmezhetők:

$t$ : naptári év

j: a gyermek születése óta eltelt évek száma

$s$ : a gyermek koréve

16 A feltételezés megkönnyíti az elemzést, hiszen a gyermekgondozási segély mellett legfeljebb heti 30 órában, a gyermekgondozási díj mellett pedig egyáltalán nem lehetett dolgozni egészen 2014. január 1-jéig. Azóta azonban az úgynevezett ,gyed extra” intézkedéscsomag többek közt engedélyezi a korlátlan munkavállalást (KSH 2015b). 
$\theta_{t}$ paraméterezéséhez a gyermekgondozási segély (gyes) átlagos értékét vettem alapul. Ennek oka az, hogy a gyes alanyi jogon jár az anyáknak, ellentétben a gyermekgondozási díjjal (gyed), amelyre nem mindenki jogosult ${ }^{17}$. A gyes átlagos értéke 2000-től 2014-ig minden évben a gyednél alacsonyabb szinten alakult ${ }^{18}$.

A gyermekre fordított közvetlen kiadásokat $\left(m_{t}^{s}\right)$ a háztartások egy före jutó éves kiadások COICOP-csoportosítás ${ }^{19}$ szerinti részletezéséből kalkuláltam. 2009-töl 2013ig rendelkezésre állt az adatok háztartások szerkezete szerinti bontása, ami alapján megbecsülhetőek az egy gyermekre fordított közvetlen kiadások. A 2 felnőtt és a 2 felnőtt 1 gyermekkel szerkezetü háztartások különbségéből adódott eredményeket átlagoltam, majd a konstans értéket vettem az elemzés teljes időhorizontjára ${ }^{20}$.

Az éves családi pótlék $\left(\alpha_{t}\right)$ a havi átlagos családi pótlékból és az egy családra jutó gyermekszámból kalkulálható. Az intézményi gyermekgondozás éves díját $\left(c_{t}^{s}\right)$ ismét a háztartások egy före jutó éves kiadások COICOP-csoportosítása segítségével állítottam elő. A kategóriák alapján elkülönítettem a tankötelezettség különböző szintjein felmerülő kiadásokat, ami alapján megbecsültem az óvoda, az alapfokú oktatás és a középfokú oktatás költségét ${ }^{21}$. Egyszerüsítésként az értékeket az elemzés időhorizontjára konstansnak, valamint szintenként változatlannak tekintem.

A humán tőke hozamát $\left(\mu_{t}\right)$ Campos és Joliffe (2007) munkája alapján paramétereztem. A reálkamatlábat $(r)$ az időszak átlagos értékén, 4,17\%-on rögzítettem, amelyből a diszkontfaktor képlet alapján számítható. Walker (1995) nyomán hasonlóan azt feltételezem, hogy $h_{l}=1, l \neq t$. Ez azt jelenti, hogy az aktuális gyermekvállalás után teljes munkaidős foglalkoztatás várható, tehát életpályája során a nő összesen egy gyermeket vállal ${ }^{22}$. A nyugdíjkorhatár értéke 65 éven rögzített, a változóra $\phi^{j}$-hez hasonlóan érzékenységvizsgálat végezhetö.

A következő alfejezetben bemutatom a gyermekvállalás árnyékárának idősorát különböző korú nők esetén. Egy rövid elemzés után, a 4. fejezettől kezdődően feltárom az összefüggéseket az árnyékár és a korábban ismertetett magyarországi jelenségek között.

17 Az igénybe vevők havi átlagos számának aránya 2003-tól 2014-ig hozzávetőlegesen 2/3-1/3 a gyes ,javára” (KSH 2016a).

18 Az összehasonlításnál fontos megjegyezni, hogy a gyes 3, a gyed pedig csak 2 évig jár. Számításaim során ezt figyelembe vettem, ennek ellenére a messze legalacsonyabb átlagkeresettel rendelkező (20 évesnél fiatalabb) korosztály esetén is a gyed volt a magasabb az átlag szintjén.

19 Classification of Individual Consumption According to Purpose, az egyéni fogyasztás rendeltetés szerinti osztályozása.

20 Walker is hasonló módszerrel becsülte a változó értékét Svédországra.

21 A bölcsőde költségét zérusnak tekintettem, mivel a bölcsődébe beíratott gyermekek aránya elhanyagolható.

22 A szigorúnak tűnő feltételezés oka az, hogy így a számítások jelentős mértékben egyszerüsödnek. Az árnyékár segítségével vizsgálandó jelenségek szempontjából a feltevés nem befolyásolja az eredményeket. 


\subsection{A gyermekvállalás árnyékárának idösorai különbözö korú nők esetén}

A gyermekvállalás árnyékárának idősorát elöször egy 25 és egy 28 éves nő esetén mutatom be. A választott korévek mögött az áll, hogy a 2000-es évek elején a szülő nők átlagos életkora az első gyermek születésekor 25 év volt, 2010-re azonban elérte a 28 évet (KSH 2015a), így az idősorok alapján láthatóvá válik a gyermekvállalás relatív, átlagos költségének alakulása. A függőleges tengely mértékegysége forintban értendö, azonban a korábbi tárgyalás alapján az abszolút értékek értelmezése félrevezető lenne, ezért csak a relatív különbségeket vizsgálom, a mértékegységet pedig idézőjelben tüntettem fel.

Az 1. ábrán jól látható, hogy a gyermekvállalás árnyékára hasonlóan alakult egy 25 és egy 28 éves nő esetén ${ }^{23}$. A jelenség oka az, hogy jelentős különbség csak az árnyékár (2.1) komponensében van, a (2.2) komponens a paraméterezés miatt egybeesik, a (2.3) pedig a nagyságrendi különbség miatt elhanyagolható. Az első komponens alakulása a 2. ábrán látható. A függőleges tengelyen az 1. és a 2. ábra között ugyan nagyságrendi eltérés áll fenn, de az elemzés szempontjából a relatív értékek számítanak. Mindkét ábra jól mutatja, hogy a korévek közötti különbség 2000-től 2005-ig nőtt, ezt követően 2006-ra hirtelen lecsökkent, majd 2014-ig trendszerűen újra növekedett. Az ábrák szerint a halasztó magatartás elsősorban 2006-tól 2008-ig jelentkezett.

\section{1. ábra: A gyermekvállalás árnyékárának idősora egy 25 és egy 28 éves nő esetén (2000-2014)}

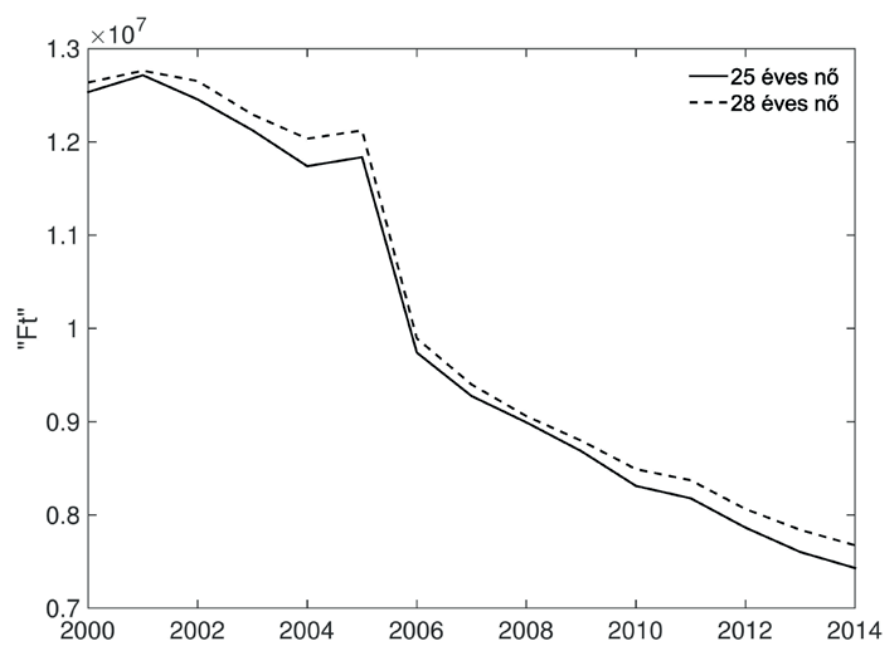

Forrás: saját készítésű ábra, az 1. táblázatban megadott források alapján

23 A 2006 óta csökkenő trend a TTR növekedésére enged következtetni. A TTR alakulását az 5. fejezetben tárgyalom. 
2. ábra: A gyermekvállalás árnyékárának első komponense egy 25 és egy 28 éves nő esetén (2000-2014)

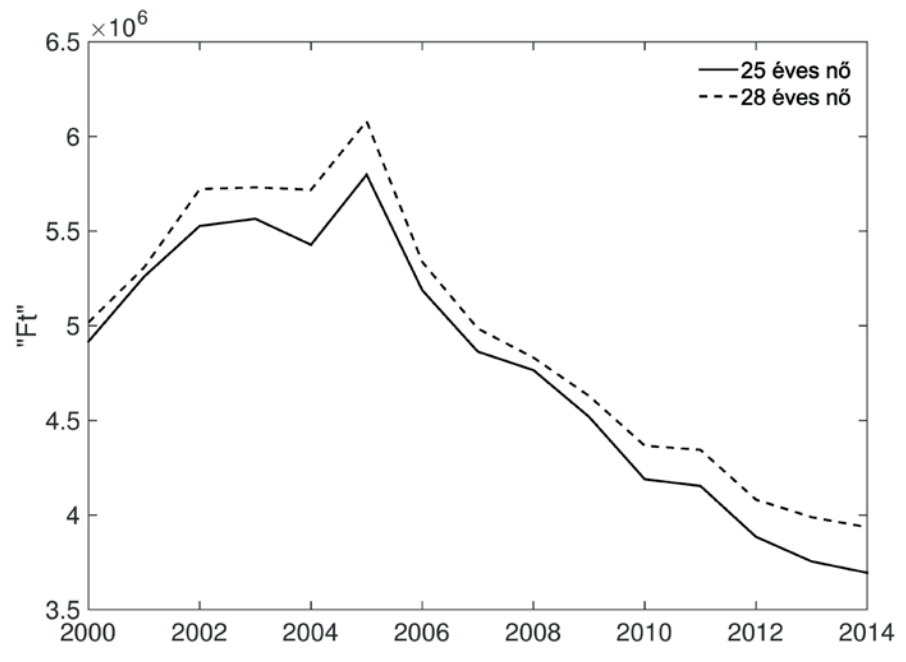

Forrás: saját készítésủ ábra, az 1. táblázatban megadott források alapján

Az 1. és 2. ábra a szülő nők átlagos életkora alapján készült (az első gyermekük születésekor). Szemléletesebb azonban a nagyobb korkülönbségre elkészített idősorok összehasonlítása. A 3. és 4. ábra 20 és 40 éves korra ábrázolja az árnyékár idősorát. Jól látható, hogy nagyobb korkülönbség esetén már markáns eltérés jelentkezik az árnyékárak között. Az eltérés oka az, hogy a legnagyobb különbség a 16-20 és a 21-25 éves korosztály átlagkeresete között jelentkezik. A csökkenő tendencia 2005-töl itt is megjelenik ${ }^{24}$, azonban ami igazán informatív, az a két vonal közötti távolság alakulása. A 3. ábrán megfigyelhető, hogy a 20 éves nők esetén 2004-ig jobban csökkent az árnyékár mint a 40 éves nők esetén. Ez arra enged következtetni, hogy a nők gyermekvállalása 2000-től 2004-ig egyre korábbra tolódott. A különbség 2008-ig csökkent, azóta pedig újra növekvő tendenciát mutat.

Az árnyékárak idősorai alapján tehát megállapítható, hogy halasztó magatartás leginkább 2005 és 2008 között jelentkezett. A következő fejezetben bemutatom a szülö nők átlagos életkorának alakulását, amelyet összevetek az árnyékárak idősora alapján kapott eredményekkel. 


\section{3. ábra: A gyermekvállalás árnyékárának idősora} egy 20 és egy 40 éves nö esetén (2000-2014)

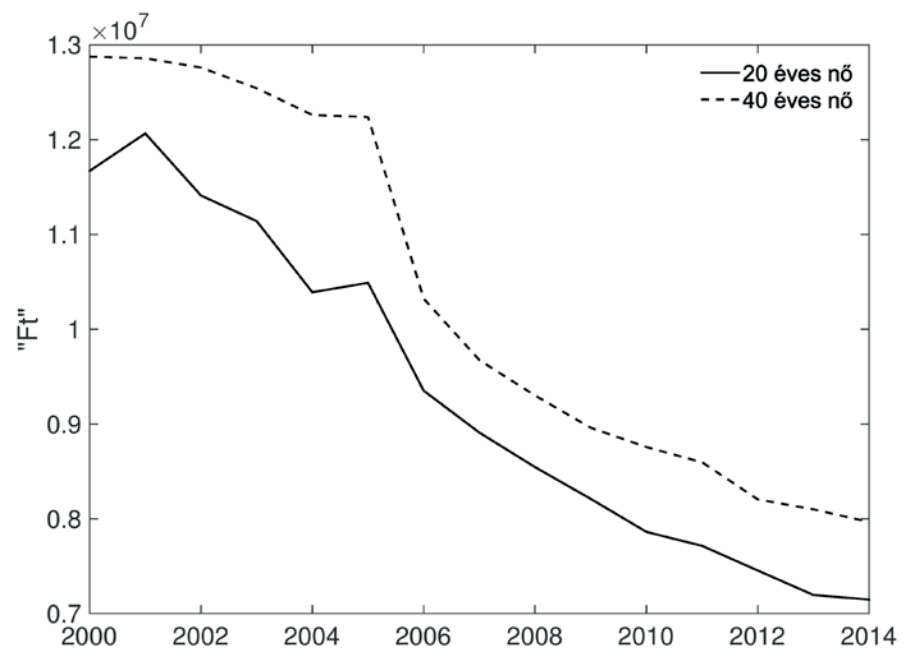

Forrás: saját készitésü ábra, az 1. táblázatban megadott források alapján

\section{4. ábra: A gyermekvállalás árnyékárának első komponense egy 20 és egy 40 éves nő esetén (2000-2014)}

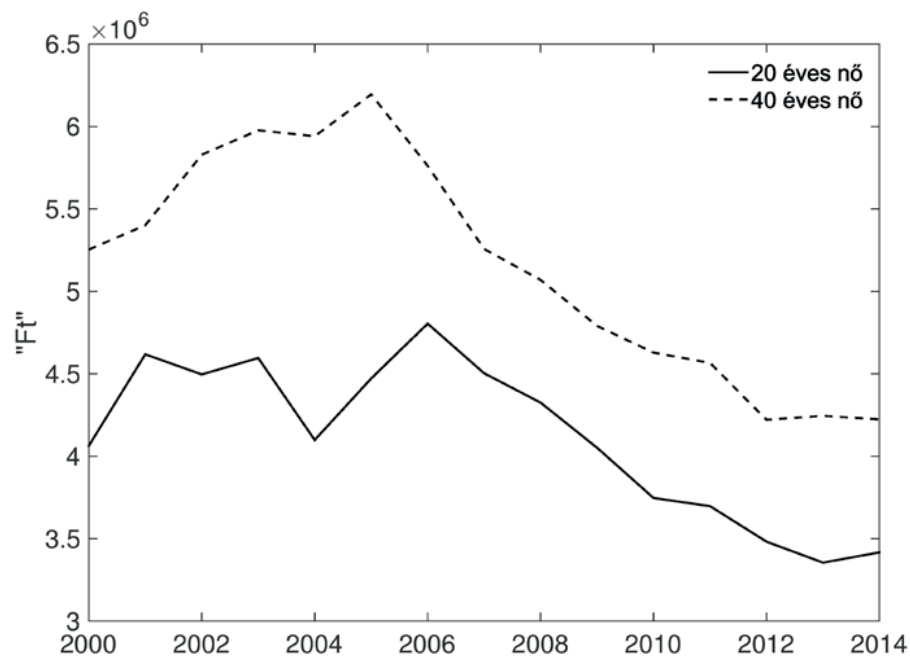

Forrás: saját készítésű ábra, az 1. táblázatban megadott források alapján 


\section{A szülő nők átlagos életkora az első gyermek születésekor}

Magyarországon a rendszerváltás óta folyamatosan emelkedik a szülő nők átlagos életkora $^{25}$. A jelenség minden paritásnál ${ }^{26}$ jelentkezik, azonban a legmarkánsabban az első paritásban nyilvánul meg (Husz 2006). Az 5. ábrán látható a szülő nők átlagos életkora az első gyermek születésekor. Az ábra alapján a vizsgált időszak elejétől 2011-ig fennáll a halasztó magatartás, amelynek üteme 2005-töl 2008-ig kis mértékben lelassult, majd 2011-ben az első paritásnál vett átlagos anyai életkor elérte a maximumát.

\section{5. ábra: A szülő nők átlagos életkorának alakulása az első paritásnál (2000-2013)}

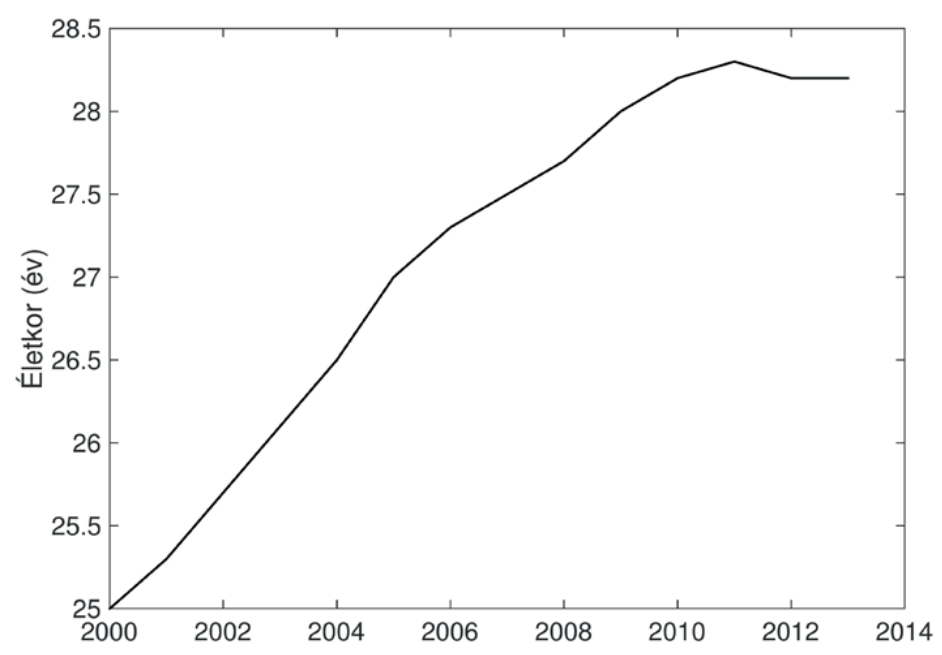

Forrás: saját készítésü ábra, KSH-adatok alapján

A MAB alakulása inkonzisztens az árnyékárak idősorai alapján kapott eredményekkel. A 3.2. alfejezet szerint a halasztó magatartás leginkább 2005 és 2008 között jelentkezett, azonban a 5. ábrán látható, hogy a halasztó magatartás pontosan ebben az időszakban lassult le. Az első paritás átlagos anyai életkora tehát elsősorban nem az árnyékár ingadozásának megfelelően alakul. Az ellentmondásnak különböző okai lehetnek. (1) Az árnyékárak idősorainak konstruálásánál feltételeztem a tökéletes informáltságot.

25 Mean Age at Birth $(M A B)$. A fejezet fennmaradó részében a MAB kifejezés az első paritásra értendö.

26 A paritás fogalma a demográfiában az élveszületések számát jelöli. Az első paritás tehát az első gyermek születését jelenti. 
A valóságban azonban elképzelhető, hogy az árnyékárat befolyásoló tényezők alakulása nem azonnal, hanem néhány év késleltetéssel épül be a várakozásokba ${ }^{27}$. (2) Egy másik ok lehet az, hogy egyéb tényezők is ösztönzik a halasztó magatartást. A 2000-es évek első felében a várható iskolázási idő kitolódása jelentkezett a közép- és felsőfokú oktatásban Magyarországon. Az átalakulás hatása megfigyelhető volt a közép- és felsőfokú végzettséggel rendelkező nők első paritás szerinti átlagos életkorában, azonban az alapfokú oktatásban részesülőkre nem volt jellemző a halasztó magatartás (Husz 2006). (3) Kamarás (2001) a halasztó magatartás okaként a hagyományos családmodell átalakulását tüntette fel. Az általa vizsgált időszak a rendszerváltást követő évtized volt. Feltételezhetö, hogy a tradicionális családmodell átalakulása a 2000-es években is folytatódott, azonban az átalakulás hatása valószínűleg kisebb, mint a rendszerváltást követő első évtizedben.

Feltehetően mindhárom tényező közrejátszott a MAB kedvezőtlen alakulásában. A jelenség mögött álló egyéb tényezők feltárása további kutatás tárgyát képezheti ${ }^{28}$. A vizsgált időszakban az első paritás átlagos életkora 2011-ben érte el maximumát, ezután 2013-ig gyakorlatilag stagnált. A gyermekvállalás biológiai határa ugyan 50 év körül alakul, de véleményem szerint nem várható a MAB 30 év feletti alakulása, mivel a késői gyermekvállalás egészségügyi kockázatokkal jár (Berkowitz és szerzőtársai 1990; Joseph és szerzőtársai 2005).

A szülő nők átlagos életkorának emelkedését okozó tényezők feltárása a demográfiai folyamatok fontos eleme. Magyarország esetében azonban a termékenység drasztikus csökkenése kiemelt jelentöséget kölcsönöz a TTR vizsgálatának. Berde és Németh (2015) 2013-ig számszerüsítette a magyar TTRp* idősorát, amely többek közt a halasztó magatartástól is szürt, így lehetővé teszi a termékenység csökkenése mögött meghúzódó tényezők parciális elemzését.

\section{A teljes termékenységi ráta alakulása mögött meghúzódó tényezők}

Magyarországon a rendszerváltást követő évtizedben a korrigálatlan teljes termékenységi ráta és a halasztó magatartás között egyértelmű negatív kapcsolat állt fenn ( $\mathrm{Ka}$ marás 2001; Husz 2006). A 2000-es évektől a kapcsolat azonban nem ennyire egyértelmü. Az 5.1. alfejezetben a TTR és a halasztó magatartás közötti kapcsolatot vizsgálom 2000 és 2013 között ${ }^{29}$.

27 Az effektív adókulcs csökkenése esetén reális feltevés, hogy a nők nem az adócsökkentés bejelentésekor realizálják a gyermekvállalás lehetőségköltségének megemelkedését, hanem csak a rendelkezésre álló jövedelmük több éves emelkedését követően.

28 Az utóbbi évtizedekben felgyorsult női emancipáció erőteljes hatása feltételezhető az anyák átlagos életkorának kitolódására.

29 A TTR-re és a TTRp*-ra adatok csak 2013-ig álltak rendelkezésre. 


\subsection{A teljes termékenységi ráta és a halasztó magatartás összefüggései}

A TTR és a MAB alakulása a 6. ábrán látható. 2000-től 2003-ig a két mutató egymással ellentétesen mozog, ahogy azt várnánk. 2004-től 2008-ig azonban a mutatók együttmozgása figyelhető meg. A MAB növekedése ellenére a TTR nem csökkent tovább, ami arra enged következtetni, hogy a TTR-t olyan pozitív sokk érhette a 2000-es évek közepén, amely ellensúlyozta a halasztó magatartás negatív hatását. 2009 után a TTR hirtelen csökkenése jelentkezett, mivel a globális pénzügyi válság következtében a gyermekvállalási kedv drasztikusan lecsökkent. A TTR 2012-re érte el a 2008 körüli szintjét, míg a MAB növekedése a válság alatt lelassult. Elképzelhető, hogy a MAB 2012-ben azért csökkent, mert a válságból való kilábalás során vissszatért a fiatalabb korosztályok gyermekvállalási kedve.

\section{6. ábra: A teljes termékenységi arányszám (TTR)} és a szülő nők átlagos életkorának (MAB) alakulása (2000-2013)

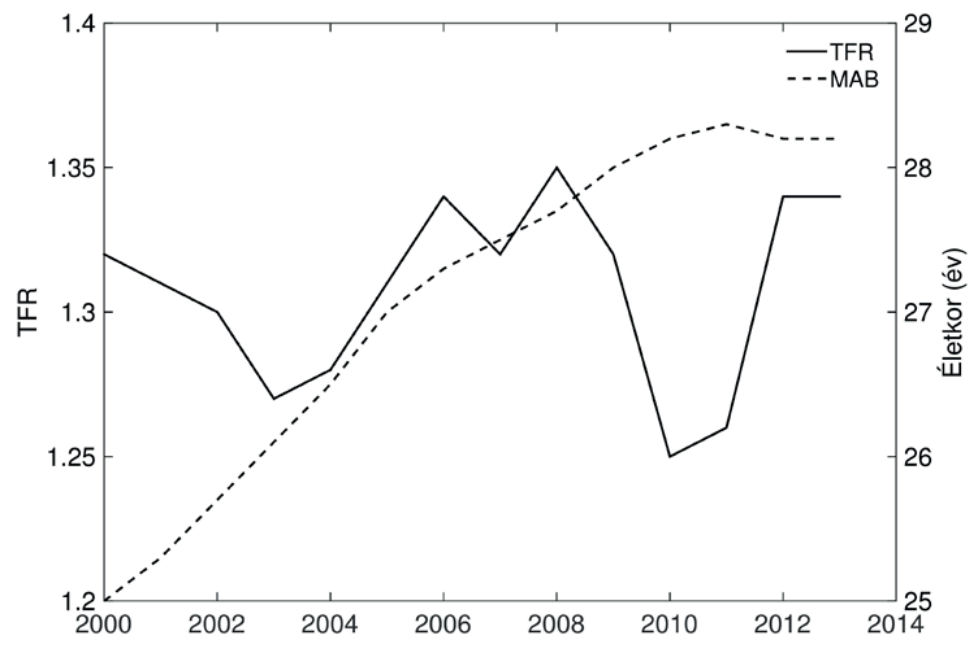

Forrás: saját készítésű ábra, KSH-adatok alapján

A termékenység csökkenő szintje mögött meghúzódó tényezők elemzéséhez azonban célszerű a halasztó magatartástól szürt mutatót vizsgálni. A TTR és a TTRp* alakulása a 7. ábrán látható. A két mutató között 2004-ig közel 50\%-os az eltérés, tehát ebben az időszakban a halasztó magatartás jelentős szerepet játszott a TTR alakulásában. A különbség 2005-től 2008-ig kis mértékben csökkent, amely a MAB jelentőségének visszaszorulására enged következtetni. A válság alatt a TTRp* drasztikus csökkenése figyelhető meg, melynek eredményeként 2012-ben átmenetileg a TTR alá esett. A je- 
lenség oka az, hogy a termékenység alakulását elsősorban nem a halasztó magatartás, hanem egyéb tényezők alakították. Az 5.2. alfejezetben az árnyékárak idősorai segítségével rávilágítok a TTRp* csökkenése mögött meghúzódó tényezőkre.

\section{7. ábra: A teljes termékenységi arányszám (TTR) és az ütem és paritás szerint korrigált teljes termékenységi ráta $\left(\mathrm{TTRp}^{\star}\right)$ alakulása (2000-2013)}

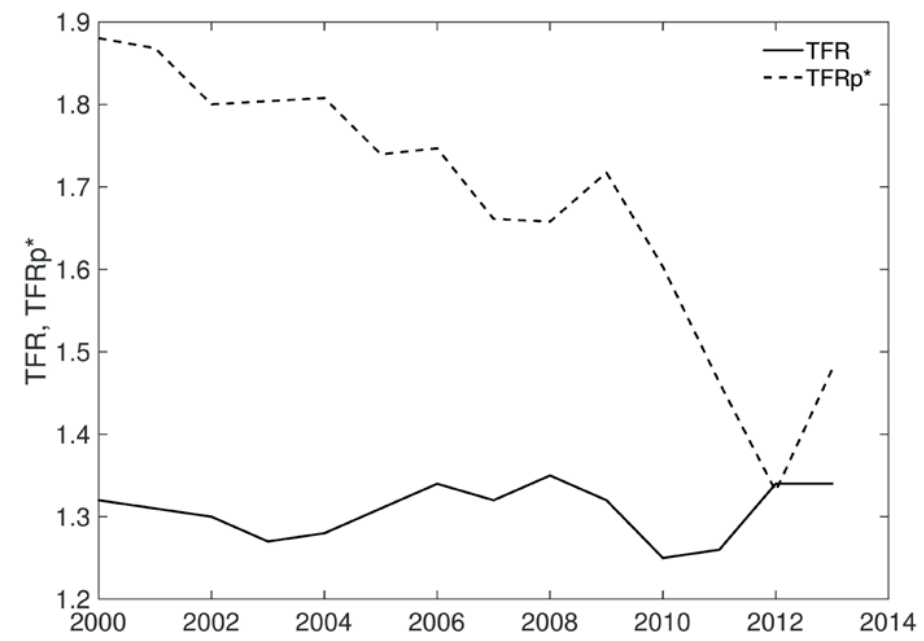

Forrás: saját készítésű ábra KSH-adatok, valamint Berde és Németh (2015) adatai alapján

\subsection{A TTR ${ }^{\star}{ }^{\star}$ s a gyermekvállalás árnyékárának idősorai}

A korábbi tárgyalás alapján láthatóvá vált, hogy a korrigálatlan teljes termékenységi ráta (TTR) tartósan alacsony szintje elsősorban a halasztó magatartás következménye. Az ütem és paritás szerint korrigált ráta $\left(\mathrm{TTRp}^{*}\right)$ folyamatos csökkenése azonban olyan változók alakulásának következménye, amelyek megjelennek a gyermekvállalás árnyékárának idősoraiban. A 8. és a 9. ábrán $n^{30}$ látható a TTRp* alakulása, valamint a gyermekvállalás árnyékárának idősora egy 20 és 40 éves nő esetén. Elméletileg a két változó között negatív kapcsolat áll fenn, hiszen a gyermekvállalás alternatívaköltségének csökkenése a termékenység növekedését eredményezné, a változók azonban inkább együttmozognak.

30 A 9. ábra korábban szerepelt már 3. ábraként, az áttekinthetőség végett azonban hasznosnak véltem újra feltüntetni. 
8. ábra: Az ütem és paritás szerint korrigált teljes termékenységi ráta $\left(\mathrm{TTR}^{*}\right)$ alakulása (2000-2013)

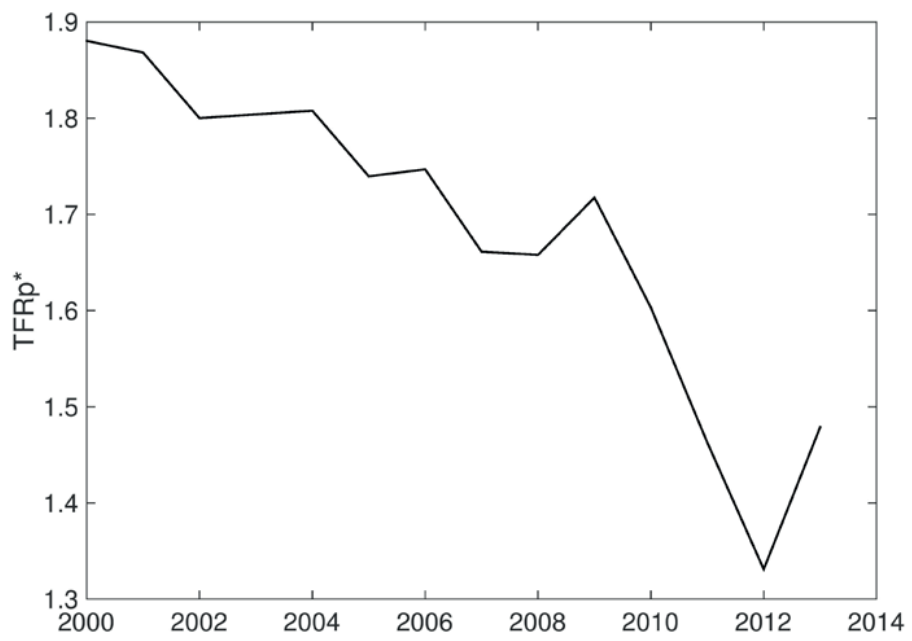

Forrás: saját készitésű ábra KSH-adatok, valamint Berde és Németh (2015) adatai alapján

9. ábra: A gyermekvállalás árnyékárának idősora egy 20 és egy 40 éves nő esetén (2000-2014)

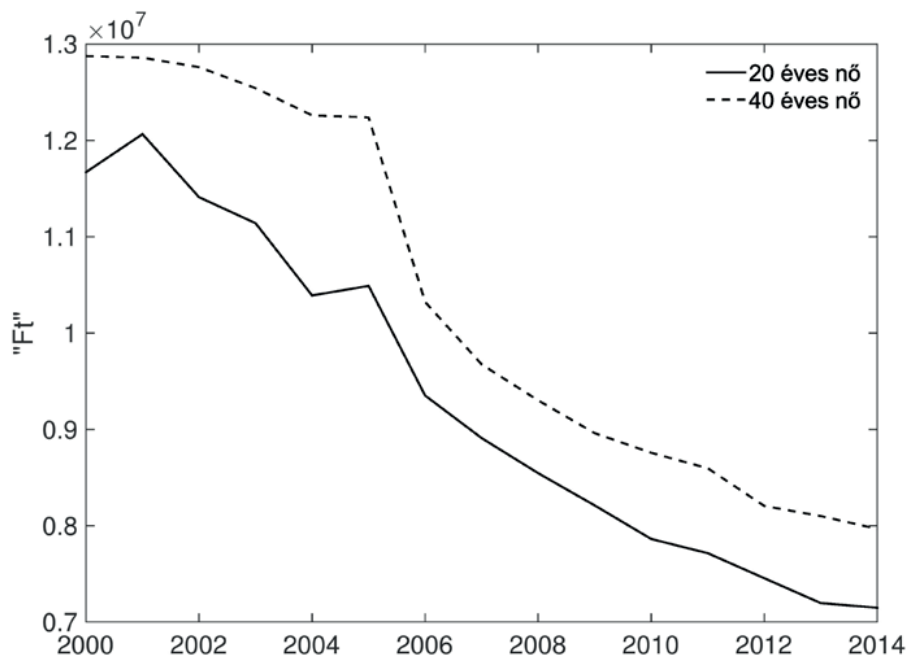

Forrás: saját készítésű ábra, az 1. táblázatban megadott források alapján 
A korrelációs együtthatók értékét a vizsgált korévekre a 2. táblázat tartalmazza. így megállapítható, hogy az árnyékár komponensei összességében nem magyarázzák jól a TTRp* alakulását ${ }^{31}$. Az árnyékár összetétele meglehetösen komplex, amely modellszemléletben nem jelent problémát, azonban a gazdasági szereplők feltehetően csak a legfontosabb, könnyen értelmezhető tényezőkre reagálnak.

\section{2. táblázat: A korrelációs együtthatók értéke a vizsgált korévek árnyékára és a TTRp ${ }^{\star}$ között (2000-2013)}

\begin{tabular}{lr}
\hline Változó & Korrelációs együttható \\
\hline$\pi(20)$ & 0,8819 \\
$\pi(25)$ & 0,8681 \\
$\pi(28)$ & 0,8590 \\
$\pi(40)$ & 0,8687
\end{tabular}

Hipotézisem az, hogy a nettó kereset ${ }^{32}$, valamint a gyermekvállaláshoz kapcsolódó transzferek ${ }^{33}$ alakulása meghatározó jelentőséggel bírnak a termékenységi döntésekre vonatkozóan elsősorban a jövedelmi hatáson keresztül. A 2. fejezetben azzal a feltételezéssel éltem, hogy a jövedelmi hatás nulla. A valóságban azonban úgy vélem, hogy a nők döntésében a jövedelmi hatás is meghatározó szerepet játszik. Ennek megfelelően a cikk fennmaradó részében parciális elemzést végzek az árnyékár egyes változóival, így a korábbi feltételezés feloldható.

\subsection{A bruttó bér és az átlagos effektív adókulcs hatásának parciális elemzése}

Hipotézisem mögött az áll, hogy a nettó kereset gyakorlatilag az anyák rendelkezésre álló jövedelme ${ }^{34}$. Ebből kifolyólag az anyák teljes mértékben szembesülnek a nettó keresetük alakulásával, amely közvetlenül azt jelenti, hogy jól informáltak a bruttó kereset és az effektív adókulcs alakulásával kapcsolatban. A szociális transzferek a mindenkori kormány programjában meghatározó jelentősséggel bírnak a szavazóbázisra, így feltételezhető, hogy a gyermekes és potenciális anyák jól informáltak a transzferekkel kapcsolatban.

A 10. ábrán látható a bruttó átlagkereset és a korrigált teljes termékenységi ráta alakulása. Elméletileg a bruttó átlagkereset emelkedésének a TTRp* csökkenését kel-

31 A korrelációs együtthatók értelmezése az idősorok rövid volta miatt félrevezető lehet. Robusztus következtetések levonása nemzetközi összehasonlítással illetve hosszabb idősorok elemzésével válik lehetővé.

32 A bruttó kereset az effektív adókulccsal csökkentve.

33 A gyermekgondozási segély és a családi pótlék.

34 A házastárs, vagy partner keresetét exogénnek tekintem. 
lene eredményeznie, hiszen a magasabb kereset növeli a gyermekvállalás lehetőségköltségét, így csökkenti a termékenységet. 2000-től 2008-ig a mutatók ezek szerint alakulnak, azonban ezután együttmozgás figyelhető meg. A jelenség oka az, hogy a válság hatására csökkent mind a bruttó átlagkereset, mind a gyermekvállalási kedv. A 11. ábra az átlagos effektív adókulcs és a TTRp* alakulását mutatja. A kettőnek elméletileg együtt kellene mozognia, mivel az adókulcs hatása a bruttó keresetével éppen ellentétes: növekvő adók esetén csökken a gyermekvállalás lehetőségköltsége, tehát nő a termékenység. Az együttmozgás az ábrán kivehető, azonban az átlagos effektív adókulcs alakulása jól mutatja a kormányzati ciklusokat: 2002, 2006 és 2010 után adóemelés, míg 2006 és 2010 elött jelentős adócsökkentés figyelhető meg. A kormányzati ciklusok következtében bekövetkezett adóváltozások 2002 és 2008 között nem hatottak a termékenység alakulására, a termékenység inkább az adók trendjére reagál. A 2010-es termékenységcsökkenés pedig inkább a válság hatásaként értelmezhető.

\section{0. ábra: A bruttó átlagkereset és az ütem és paritás szerint korrigált teljes termékenységi ráta $\left(\mathrm{TTR}^{*}\right)$ alakulása (2000-2013)}

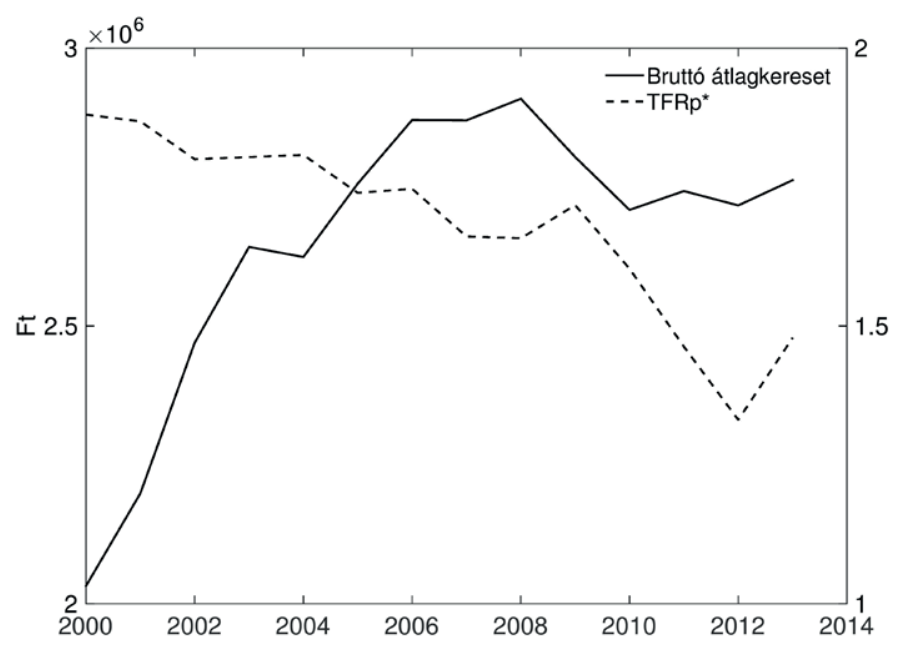

Forrás: saját készítésű ábra, az 1. táblázatban megadott források alapján

A 3. táblázat tartalmazza a korrelációs együtthatók értékét a bruttó átlagkereset és az átlagos effektív adókulcs egyidejü, 1, illetve 2 évvel korábbi ${ }^{35}$ értékei, valamint az ütem és paritás szerint korrigált teljes termékenységi ráta között. Abszolút értékben minden együttható 0,5 feletti, ami azt jelenti, hogy a kereset és a TTRp* , valamint az adókulcs és a TTRp között a közepesnél erősebb kapcsolat mutatkozik minden lead-re ${ }^{36}$.

$35-1$ és -2 lead.

36 Fontos megjegyzés, hogy eltolt idősorok korrelációja során adatvesztés történik. 


\section{1. ábra: Az átlagos effektív adókulcs és az ütem és paritás szerint korrigált teljes termékenységi ráta $\left(\mathrm{TTR}^{\star}\right)$ alakulása $(2000-2013)$}

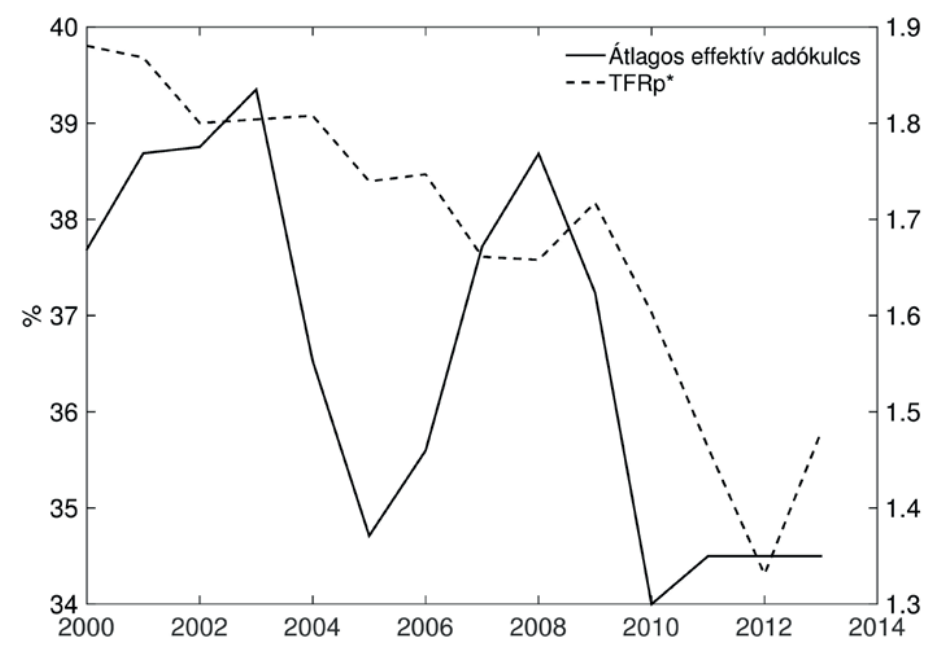

Forrás: saját készítésủ ábra, az 1. táblázatban megadott források alapján

3. táblázat: A korrelációs együtthatók értéke a bruttó átlagkereset és az átlagos effektív adókulcs, valamint a TTRp között (2000-2013)

\begin{tabular}{lr}
\hline Változó & Korrelációs együttható \\
\hline $\operatorname{mean}(w)$ & $-0,5318$ \\
$\operatorname{mean}\left(w_{-1}\right)$ & $-0,5143$ \\
$\operatorname{mean}\left(w_{-2}\right)$ & $\mathbf{- 0 , 5 4 0 8}$ \\
$\operatorname{mean}(\tau)$ & 0,6812 \\
$\operatorname{mean}\left(\tau_{-1}\right)$ & $\mathbf{0 , 7 4 4 4}$ \\
$\operatorname{mean}\left(\tau_{-2}\right)$ & 0,6594
\end{tabular}

Változónként a legmagasabb korrelációs együtthatót vastaggal jelöltem. Az értékek alapján látható, hogy a kereset hatása a termékenységre leginkább 2 év késéssel, az adókulcsé pedig 1 év késéssel jelentkezik. A jelenség oka az, hogy a gyermekvállalásról a nők legkorábban 9 hónappal korábban dönthetnek, ami kerekítve egy éves késést jelent. A legmarkánsabb relatív eltérés az adókulcs egyidejü és 1 évvel korábbi értéke között áll fenn, mivel az adókulcs változásának bejelentése általában a változás előtt 1 évvel történik. 
Az elemzés alapján azt a következtetést lehet levonni, hogy a termékenység eröteljesen reagál a keresetben és az adókulcsban történő változásokra. A reakció azonban nem egyidejü, hanem leginkább 1 éves késéssel jelentkezik ${ }^{37}$. A kormányzat ezek alapján az átlagos effektív adókulcs módosításával erőteljes hatást gyakorolhat a termékenység alakulására. A termékenységet tehát az SZJA és a munkavállalói járulékok növelésével lehet ösztönözni, mivel ezáltal csökken a gyermekvállalás lehetőségköltsége. Fontos azonban megjegyezni, hogy a túlzott adóztatás negatív hatással lehet a gyermekvállalási kedvre, hiszen az anyagi biztonság hiányában a nők nem adhatják fel munkahelyüket a gyermekvállalásért ${ }^{38}$.

\subsection{A gyermekvállaláshoz kapcsolódó transzferek hatásának parciális elemzése}

Hipotézisem második fele az volt, hogy a gyermekvállaláshoz kapcsolódó transzferek alakulása erőteljesen befolyásolja a termékenységi döntéseket. A 12. és a 13. ábrán látható rendre a gyermekvállalási segély és a TTRp* alakulása, valamint a családi pótlék és a TTRp alakulása 2000-től 2013-ig. Elméletileg a kapcsolat pozitív, hiszen a transzferek a gyermekvállalást hivatottak ösztönözni. Az ábrákon azonban pozitív kapcsolat csak 2006-tól figyelhető meg, 2000-től 2006-ig a kapcoslat inkább negatív. Látható, hogy 2000 és 2006 között a gyes majdnem 20\%-kal, míg a családi pótlék csaknem 85\%-kal emelkedett. A TTRp* csökkenő trendje azonban ennek ellenére változatlan maradt. 2006-tól 2013-ig a kapcsolat pozitív, azonban felvetödik a kérdés, hogy ez valóban ok-okozati kapcsolat, vagy az együttmozgás látens. Véleményem szerint az utóbbi áll fenn, hiszen a válság éveiben mind a gyes, mind a családi pótlék csökkenő tendenciát mutat. A gyermekvállalási kedv pedig a korábbi tárgyalás alapján válság esetén visszaesik.

A teljesség kedvéért a 4. táblázatban feltüntettem a korrelációs együtthatók értékét a transzferek egyidejü, valamint egyes lead értékeire. A gyes és a TTRp* egyidejü értékei között a közepesnél gyengébb, míg a családi pótlék és a TTRp* egyidejü értékei között gyenge a kapcsolat. A lead értékeknél a kapcsolat iránya megfordul, ami ellentmond az intuíciónak. A korrelációk lényegi értelmezése félrevezető lenne, mivel a válság következtében erőteljes csökkenés figyelhető meg mind a transzferek, mind a gyermekvállalási kedv alakulásában. Emiatt a valós összefüggések feltárásához hosszabb idősorok elemzése szükséges, amely további kutatás tárgyát képezheti.

37 A korrelációs együtthatók értelmezése az idősorok rövid volta miatt félrevezető lehet. Robusztus következtetések levonása nemzetközi összehasonlítással illetve hosszabb idősorok elemzésével válik lehetővé.

38 A termékenységi döntésre közvetlenül a házastárs, vagy a partner jövedelme is hatással van, amely hasonlóan függ az adóktól. 
12. ábra: A gyermekvállalási segély és az ütem és paritás szerint korrigált teljes termékenységi ráta $\left(\mathrm{TTR}^{\star}\right)$ alakulása $(2000-2013)$

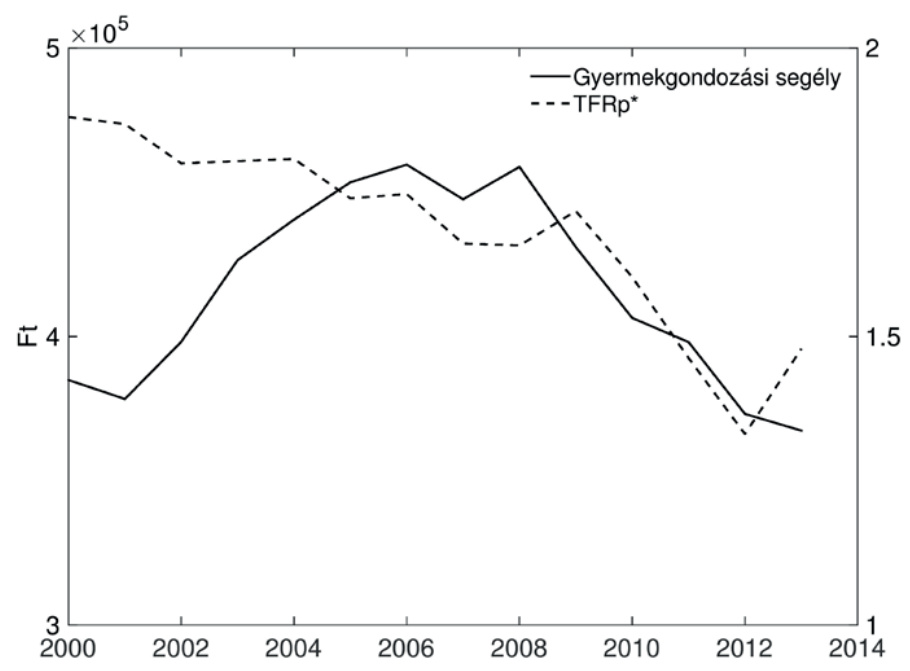

13. ábra: A családi pótlék és az ütem és paritás szerint korrigált teljes termékenységi ráta $\left(\mathrm{TTR}^{*}\right)$ alakulása $(2000-2013)$

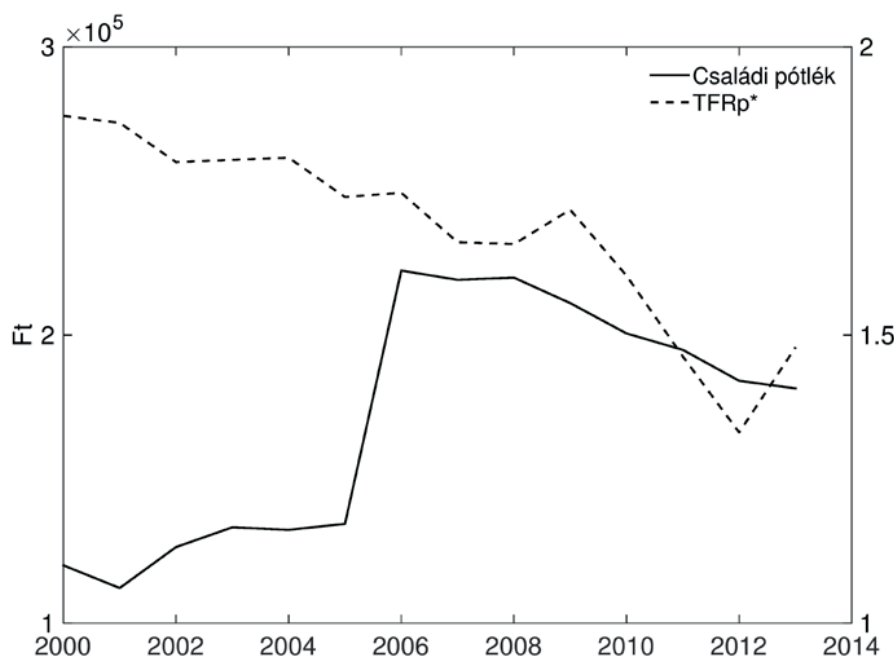


4. táblázat: A korrelációs együtthatók értéke a gyermekvállaláshoz kapcsolódó állami transzferek és a TTRp* között (2000-2013)

\begin{tabular}{lr}
\hline Változó & Korrelációs együttható \\
\hline$\theta_{t}$ & 0,3184 \\
$\theta_{-1}$ & 0,1533 \\
$\theta_{-2}$ & $-0,1173$ \\
$\alpha$ & $-0,5555$ \\
$\alpha_{-1}$ & $-0,6294$ \\
$\alpha_{-2}$ & $-0,1173$
\end{tabular}

\section{Az elemzés során levonható következtetések összegzése}

A 3. fejezetben bemutattam a gyermekvállalás árnyékárának idősorait az első paritásra. A különböző korosztályokra elkészített idősorok többnyire együttmozogtak, hiszen az árnyékárak egyes változói ${ }^{39}$ függetlenek az anyai életkortól. Az eltérések elsősorban a korcsoportonként különböző nettó keresetből adódtak. Az árnyékárak idősorainak segítségével feltárhatóvá válnak a szülő nők átlagos életkorának kitólódása ${ }^{40}$, valamint az ütem és paritás szerint teljes termékenységi ráta mögött meghúzódó tényezők.

\subsection{A halasztó magatartást magyarázó tényezök}

A 4. fejezetben a halasztó magatartás alakulását elemeztem az árnyékárak segítségével. Az 5. ábra mutatta a szülő nők átlagos életkorának trendszerü, de valamelyest lassuló növekedését. Az árnyékárak idősorai (1. és 3. ábra) akkor magyarázták volna jól a halasztó magatartást, ha a fiatalabb és az idősebb korévek idősora egymáshoz közelített volna. Ekkor az árnyékár komponenseivel végzett hasonló összehasonlítás megadta volna, hogy melyik komponens (és melyik változók) alakulása hat leginkább a halasztó magatartásra. Az 1. és 3. ábra idősorai inkább távolodnak egymástól, ami arra enged következtetni, hogy a halasztó magatartás nem az árnyékárat alkotó komponensek és változók, hanem más tényezők következménye. Az árnyékár a gyermekvállalás miatti minden olyan direkt és indirekt költséget tartalmazza, amely pénzben kifejezhető. Ez alapján a szülő nők átlagos életkorának kitolódása nem, vagy csak rendkívül közvetett módon kapcsolódik a pénzben kifejezhető költségekhez. Kamarás (2001) szerint a hagyományos családmodell átalakulása, Husz (2006) szerint az oktatásban megjelenő

39 A gyermek iskoláztatása, ruháztatása, a családi pótlék mértéke stb.

40 Ezt a jelenséget neveztem halasztó magatartásnak. 
változások is erőteljes hatást gyakorolnak a halasztó magatartásra. A tény, hogy az árnyékárak idősorai nem magyarázták megfelelően a halasztó magatartást, mindkét szerző hipotézisét igazolja, így az eredmények konzisztensek. Feltételezhetően egyéb tényezők is előidézik a halasztó magatartást, melyek feltárásához érdemes a problémát nemzetközi környezetben vizsgálni.

\subsection{A termékenység alakulását magyarázó tényezők}

Az 5. fejezetben az ütem és paritás szerint korrigált teljes termékenységi ráta alakulását vizsgáltam az árnyékárak segítségével. A fejezet elején Berde és Németh (2015) nyomán röviden érveltem amellett, hogy az elemzés során a korrigált teljes termékenységi ráta alakulását célszerű figyelembe venni, és ennek megfelelően jártam el. Az árnyékárak idősorai és a termékenység alakulása közötti kapcsolat elméletileg negatív, hiszen a gyermekvállalás árnyékárának emelkedése (csökkenése) a termékenységet negatívan (pozitívan) ösztönzi. Az általam elkészített idősorok és a TTRp* alakulása között azonban a kapcsolat ránézésre is pozitív (8. és 9. ábra), amit a korrelációs együtthatók értéke is alátámaszt (2. táblázat). Ezek alapján az árnyékár komponensei nem magyarázzák jól a termékenység alakulását, sőt, félrevezető következtetésekre vezetnek. Az ellentmondás oka a gazdasági és pénzügyi ciklusokban keresendő. A gyermekvállalás árnyékárának legtöbb változója erőteljesen ciklikus, így a 2008-as globális pénzügyi válság hatása megfigyelhető az árnyékárak idősoraiban. A gazdasági és pénzügyi ciklusok azonban a gyermekvállalási kedvet is befolyásolják ${ }^{41}$.

\subsection{A termékenység pozitív ösztönzése}

Kutatásom célkitüzései között szerepelt, hogy olyan ajánlásokat fogalmazzak meg a gazdaságpolitikai döntéshozó számára, ami alapján ösztönözheti a gyermekvállalást. Ezt az egyes változók hatásának parciális elemzése alapján tettem meg. Az előző bekezdésben felhívtam a figyelmet arra, hogy a gazdasági és pénzügyi ciklusok „elrontják” az árnyékárral való elemzést, hiszen mind az ok, mind az okozat reagál a ciklusokra. Célom tehát az volt, hogy olyan aciklikus változót keressek, amelyet a kormányzat legalább közvetett módon képes befolyásolni. Kiindulásként az árnyékárat jelentős mértékben meghatározó komponenseket vizsgáltam.

Az 5.3. alfejezetben a bruttó átlagkereset és az átlagos effektív adókulcs hatását elemeztem. A 10. ábrán látható, hogy a bruttó átlagkereset és a termékenység közötti összefüggés negatív, azonban az is megfigyelhető, hogy a bér alakulása is ciklikus.

41 Az összefüggés intuitíve fennáll, de egyszerű módon belátható. Tegyük fel, hogy a gyermekvállalási kedv független a gazdasági és pénzügyi ciklusoktól. A termékenységnek ekkor jelentős mértékben növekednie kellene az árnyékár csökkenésekor. Az idősorok azonban együttmozognak, így a gyermekvállalási kedv is szükségszerüen függ a ciklusoktól. 
A 11. ábra alapján az átlagos effektív adókulcs és a TTRp* között pozitív kapcsolat áll fenn, valamint $\tau_{t}$ alakulásában a válság hatása mellett más is megfigyelhető. $\mathrm{Az}$ effektív adókulcs változása erőteljesen függ a kormányzati ciklusoktól. Elsősorban az figyelhető meg, hogy a 2006-os és a 2010-es választási évek előtt meredeken csökkent, ezt követően pedig emelkedett. $\tau_{t}$ tehát egy olyan változó, amely aciklikus és a gazdaságpolitikai döntéshozó közvetlenül tudja befolyásolni. Az átlagos effektív adókulcs, tehát a személyi jövedelemadó és a munkavállalói járulékok pályájának megválasztásával ösztönözhető a termékenység, mégpedig a következő módon. $\tau_{t}$ és TTRp* között a kapcsolat a közepesnél erősebb és pozitív (3. táblázat), tehát a munkát terhelő adók növelésével a gyermekvállalás pozitívan ösztönözhetö. Az adóeemelésnek azonban korlátja a rendelkezésre álló jövedelem túlzott csökkenése ${ }^{42}$. Fontos megjegyezni, hogy az elemzés során munkát terhelő adók hatását vizsgáltam. Mikroökonómiából jól ismert, hogy az egyösszegű adó preferált a termelési tényezőket terhelő adókkal szemben, mivel semleges (nem befolyásolja a gazdasági szereplők viselkedését), ellenben nem, vagy nehezen megvalósítható. A termékenység ösztönzésénél azonban a cél a gazdasági szereplők viselkedésének megváltoztatása, amely a munkát terhelő adók növelése által a kívánatos irányban befolyásolható. Az adóztatás emellett megvalósítható, mivel az adóalap jól definiált. A gazdaságpolitikai döntéshozó tehát a munkát terhelö adók növelése által ösztönözheti a gyermekvállalást, amely intézkedés a megfigyelések alapján aciklikus és elméletileg megvalósítható.

Az 5.4. alfejezetben a gyermekvállaláshoz kapcsolódó transzferek hatását elemeztem. A 12. és a 13. ábrán látható az egyes transzferek és a TTRp* idősora. Együttmozgásról egyik esetben sem beszélhetünk, amit a korrelációs együtthatók értékei is alátámasztanak (4. táblázat). Az ábrákon megfigyelhető, hogy a transzferek jelentős növelésére a termékenység egyáltalán nem reagált. Az ösztönző hatás hiánya miatt a gazdaságpolitikai döntéshozó a transzferek növelésével tehát nem tudja befolyásolni a termékenységet ${ }^{43}$. A nem várt eredmény oka az, hogy mind a gyes, mind a családi pótlék ciklikus. Az ábrákon megfigyelhetö, hogy a válság kitörése óta a transzfereket csökkenő pálya jellemzi. A korábbi tárgyalás alapján ciklikus változókkal a termékenység nem ösztönözhetö.

42 Ekkor az anyagi bizonytalanság feltehetően csökkenti a gyermekvállalási kedvet.

43 A transzferek a költségvetési kiadások növelését jelentenék. Első pillantásra úgy tűnhet, hogy az intézkedés nem fenntartható. Ha azonban a transzfereket a kormányzat munkát terhelő adókból finanszírozza, az intézkedések megvalósíthatóak és fenntarthatóak, hiszen elméletileg mindkét intézkedés ösztönzi a gyermekvállalást. 


\section{7. Összefoglalás}

Kutatásom elsősorban az ütem és paritás szerint korrigált teljes termékenységi ráta alakulása mögött meghúzódó tényezők feltárására irányult. Az elemzéshez Walker neoklasszikus modelljét vettem segítségül, melynek elsőrendű feltétele megadja a gyermekvállalás árnyékárának egyenletét. Az egyenletet empirikus magyar adatokkal paramétereztem és elkészítettem a gyermekvállalás árnyékárának idősorát különböző korú nők esetén. Az elkészített idősorok segítségével először az átlagos anyai életkor kitolódását, az úgynevezett halasztó magatartást próbáltam magyarázni az első paritásra. Az árnyékárak alakulása nem magyarázta jól a jelenséget, a lehetséges okok feltüntetésével további kutatási irányokat jelöltem ki.

$\mathrm{Az}$ 5. fejezetben részletesen vizsgáltam a teljes termékenységi ráta alakulását. Rámutattam, hogy a korrigálatlan teljes termékenységi ráta elemzése félrevezetö lenne, mivel a halasztó magatartás következtében erősen torzított. Az ütem és paritás szerint korrigált teljes termékenységi rátát elöször a gyermekvállalás árnyékárának idősoraival vetettem össze. Ennek során, elsősorban a 2008-as globális pénzügyi válság miatt, félrevezető eredményeket kaptam, hiszen nemcsak a modell számos komponense, hanem a gyermekvállalási kedv is jelentős mértékben függ a gazdasági és pénzügyi ciklusoktól. A korrigált teljes termékenységi rátát ebből kifolyólag parciális elemzésnek vetettem alá. A 6. fejezetben többek közt bemutattam, hogy a bruttó kereset és az effektív adókulcs alakulása erőteljes hatást gyakorol a termékenységre, így a gazdaságpolitikai döntéshozó a személyi munkajövedelemadó és a munkavállalói transzferek alakításával ösztönözheti a gyermekvállalást. Emellett beláttam, hogy a gyermekgondozáshoz kapcsolódó transzferek jelentős emelése sem képes befolyásolni a termékenységet.

\section{Köszönetnyilvánítás}

A szerzö köszönetét fejezi ki Dr. Berde Évának értékes megjegyzéseiért, javaslataiért. A fennmaradó hibákért a felelösség kizárólag a szerzőt terheli.

\section{Függelék}

\section{A. A gyermekvállalás árnyékárának egyenletéhez használt változók számításának módja}

\section{A.1 $w_{t}$}

A változó számszerüsítése során három forrást használtam. Két forrás (KSH 2007; Nemzeti Foglalkoztatási Szolgálat 2014) segítségével összeállítottam a korcsoportos női bérek arányát az átlagbérhez képest. Az átlagkereseteket (KSH 2016b) súlyozva és a fogyasztói árindexszel korrigálva előállítottam a nők éves bruttó reálkeresetét korcsoportok szerint. 


\section{A.2 $\tau_{t}$}

A $w_{t}$ értékeire az adótáblák (Nettó bér kalkulátor 2014) alapján kalkuláltam az effektív személyi jövedelemadót sávonként, az alábbi képlet szerint:

$$
\text { ef.SZJA }=\frac{T+(B-L) T_{L}}{B},
$$

ahol $T$ a sávhoz tartozó egyösszegű adó, $B$ az adóalap ${ }^{44}, L$ az alsó sávhatár, $T_{L}$ pedig a sávhoz tartozó adókulcs.

Ezután az effektív adókulcs kiszámításához az effektív SZJA értékéhez hozzáadtam az adott évi munkavállalói járulékok (Társadalomkutatási Intézet Rt. 2009; Nemzeti Adóés Vámhivatal 2016) összegét, így megkaptam $\tau_{t}$ értékét korcsoportok szerint.

\section{$A .3 m_{t}^{s}$}

A gyermek miatt felmerülő közvetlen kiadásokat a háztartások egy főre jutó éves kiadások COICOP-csoportosítása szerinti részletezése alapján (KSH 2010, 2011, 2012a, 2012b, 2013a, 2013b, 2014a) kalkuláltam. Kétféle háztartástípust vetettem össze: 2 felnőtt gyermek nélkül és 1 gyermekkel ${ }^{45}$. A kiadásokat elöször felszoroztam a háztartások létszámával, majd a különbség megadta a gyermek miatti pluszkiadásokat. Az 5 különböző évre kapott, fogyasztói árindexszel korrigált értékeket átlagoltam, majd konstansnak vettem az elemzés teljes horizontjára.

\section{A.4 $\alpha_{t}$}

Az egy főre jutó átlagos családi pótlék adatsorát (KSH 2014b) kis mértékben módosítani kellett. Az egy családra jutó átlagos értéket elosztottam az egy családra jutó átlagos gyermekszámmal, így megkaptam az egy gyermekre jutó átlagot. A havi értéket 12vel szorozva, majd a fogyasztói árindexszel korrigálva megkaptam a számítások során használt értéket.

\section{A.5 $c_{t}^{s}$}

Az intézményi gyermekgondozás költségének becsléséhez is a háztartások egy före jutó éves kiadások COICOP-csoportosítás szerinti felméréséből indultam ki. Számításaim során a legfrissebb, 2013-as felmérés (KSH 2014a) adatait használtam fel. A vizs-

44 2010-től 2012-ig szuperbruttó adóalappal kellett számolni, amely az eredeti adóalap 127\%-át jelentette. (2012-ben csak bizonyos sávhatártól kellett szuperbruttó adóalappal számolni.)

45 Az elemzés során az első paritást vizsgáltam, így az adatgyűjtés is ezt tükrözi. 
gált háztartástípusok: 2 felnőtt gyermek nélkül és 1 gyermekkel. A csoportosításban olyan tételek szerepeltek, mint az „óvodai étkezés”, az „elolkészítő és alapfokú oktatás”, a „munkahelyi és diákétkeztetés” és a „középfokú oktatás”46. A 2 felnőtt, 1 gyermekes háztartásokban a tanulók ${ }^{47}$ aránya 19,4\% volt, ezért a különböző tételeket $\frac{1}{0,194}$-del szorozva megkaptam a tételek hipotetikus értékét 1 tanulóra. Ezután a két háztartástípus közötti különbségeket véve:

(1) az intézményi gyermekgondozás díja a tankötelezettség óvodás korában (3-6 év) a fentiek szerint kalkulált „óvodai étkezés”,

(2) az alapfokú oktatás alatt (7-14 év) az „előkészítő és alapfokú oktatás” és a „munkahelyi és diákétkeztetés” összege,

(3) 15-18 éves korig a „középfokú oktatás” értéke.

\section{Hivatkozások}

Berde Éva - Németh Petra (2015): Csehország, Magyarország és Szlovákia termékenységi idősorainak összehasonlítása. Statisztikai Szemle, Vol. 93, No. 2:113-141.

Berkowitz, G. S. - Skovron, M. L. - Lapinski, R. H. - Berkowitz, R. L. (1990): Delayed childbearing and the outcome of pregnancy. New England Journal of Medicine, 322(10):659-664.

Bongaarts, J. - Feeney, G. (2008): The quantum and tempo of life-cycle events. In How Long Do We Live? Springer Berlin Heidelberg:29-65.

Campos, N. - Jolliffe, D. (2007): Earnings, schooling, and economic reform: econometric evidence from Hungary (1986-2004). The World Bank Economic Review, Vol. 21, No. 3:509-526.

Espenshade, T. J. - Guzman, J. C. - Westoff, C. F. (2003): The surprising global variation in replacement fertility. Population Research and Policy Review, Vol. 22, No. 5:575-583.

Husz Ildikó (2006): Iskolázottság és a gyermekvállalás időzítése. Demográfia, Vol. 49, No. 1:46-67.

Joseph, K. S. - Allen, A. C. - Dodds, L. - Turner, L. A. - Scott, H. - Liston, R. (2005): The perinatal effects of delayed childbearing. Obstetrics \& Gynecology, Vol. 105, No. 6:1410-1418.

Kamarás Ferenc (2001): Családalapítás és gyermekvállalás az 1990-es években és az ezredfordulón. Demográfia, Vol. 44, No. 1-2:44-73.

46 A gyermektelen háztartásoknál a „munkahelyi és diákétkeztetés” kivételével a felsorolt tételek gyakorlatilag 0 Ft-ot tettek ki.

47 A tanuló itt definíciószerűen a 3-18 éves (tankötelezett) korosztályt jelenti. 
Kohler, H.-P. - Ortega, J. A. (2004): Tempo-adjusted period parity progression measures, fertility postponement and completed cohort fertility. Demographic research, Vol. 6, No. 6:91-144.

KSH (2007): Foglalkoztatottság és kereseti arányok 1998-2005. Munkaügyi adattár. http://goo.gl/uIW6zo, Letöltve: 2016. 03. 22.

KSH (2010): A háztartások fogyasztásának színvonala és szerkezete, 2009 - táblázatok. http://goo.gl/lpHa5S, Letöltve: 2016. 03. 22.

KSH (2011): A háztartások fogyasztásának színvonala és szerkezete, 2010 - táblázatok. http://goo.gl/xgvlSQ, Letöltve: 2016. 03. 22.

KSH (2012a): A gyermek nélküli háztartások adatai. http://goo.gl/n742Xc, Letöltve: 2016. 03. 22.

KSH (2012b): A gyermekes háztartások adatai. http://goo.gl/QX3w4c, Letöltve: 2016. 03. 22.

KSH (2013a): A gyermek nélküli háztartások adatai. http://goo.gl/pKfTEr, Letöltve: 2016. 03. 22.

KSH (2013b): A gyermekes háztartások adatai. http://goo.gl/vQ96yV, Letöltve: 2016. 03. 22.

KSH (2014a): A háztartások életszínvonala. http://goo.gl/RzlCnE, Letöltve: 2016. 03. 22.

KSH (2014b): Szociális Statisztikai Évkönyv, 2013.

KSH (2015a): Demográfiai Évkönyv, 2014.

KSH (2015b): A kisgyermeket nevelő nő és a munkaerőpiac. Statisztikai Tükör, $2015 / 55$.

KSH (2016a): STADAT - Családi pótlék, gyermekgondozási segély és díj (1990-). https://goo.gl/q9iqwt, Letöltve: 2016. 03. 22.

KSH (2016b): STADAT - Foglalkoztatottság, munkaerö, keresetek. http://goo.gl/ei5Fxa, Letöltve: 2016. 03. 22.

Lucas, R. E. (1976): Econometric policy evaluation: A critique. In Carnegie-Rochester conference series on public policy, Vol. 1:19-46.

Nemzeti Adó- és Vámhivatal (2016): Fizetendő járulékok 2010-2016. http://goo.gl/ OU4FCa, Letöltve: 2016. 03. 22.

Nemzeti Foglalkoztatási Szolgálat (2014): Egyéni bérek és keresetek statisztikája 2002-2014. http://goo.gl/lkmI9K, Letöltve: 2016. 03. 22.

Nettó bér kalkulátor (2014): SZJA adótáblák alakulása 1988-tól. http://goo.gl/lyJbrz, letöltve: 2016. 03. 22.

Sato, Y. (2007): Economic geography, fertility and migration. Journal of Urban Economics, Vol. 61, No. 2:372-387.

Temesi József - Varró Zoltán (2007): Operációkutatás. Aula, Budapest.

Társadalomkutatási Intézet Rt. (2009): A munkavállalói nyugdíj- és egészségbiztosítási járulék 1993-2002. http://goo.gl/uU5a12, Letöltve: 2016. 03. 22. 
Világbank (2016): Real interest rate. http://goo.gl/PDpGzI.

Walker, J. R. (1995): The effect of public policies on recent Swedish fertility behavior. Journal of population economics, Vol. 8, No. 3:223-251. 